\title{
Transitions Effect on Basketball Matches Results
}

\author{
Sara Helmy Moselhy *
}

\section{Introduction:}

Basketball is a game of speed and reaction - all movements should focus on these componence to get a high score (Krause \& Pim, 2002, p. 387; Krause, D. Meyer \& Meyer, 1999, p. 2). It is a game of percentages in which players try to score the highest points to win the game, Dean Smith said commented on that saying "the object of basketball offensively is to score two points on every possession, and ideally three points" (Krause, 1994, p. 155, 162). It is a fast-changing game in which the players are making quick transitions from defense to offense or vice versa in heated confrontations (Chen et al., 2016).

Transitions are the action of shifting from defense to offense (offensive transition), or offense to defense (defensive transition). Developing a strong transition is key to a team's overall success, Joe Haefner said in his article "To be successful at any level, players need to manage transitions in a game" (Haefner, 2010; Peterman, 2014).

Very quick transitions are very popular with players as they involve everyone in making scoring opportunities, they are also loved by the fans as they get all excited by the speed, the action, and the consecutive scoring points. It is a key component in the success of basketball teams, whether it is an offensive or defensive transition (Krause \& Pim, 2002, p. 261, 265).

A great offensive transition is to pass the ball and limit dribbling in few seconds reaching the basket, these several major rule changes have helped popularize the quick transition, such as the eight seconds rule and twenty four seconds rule (Krause \& Pim, 2002, p. 261). Great defensive transition is to employ a full-court pressing defense, which can be a simple full-court man-to-man pressure or one of the various pressure zones in few seconds to defend the basket and prevent scoring points (Lenox \& Murphy, 2010, p. 37).

A basketball game is called a game of seconds, meaning that it is important to do transition offense or defense in few seconds saving the remaining twenty four seconds of offensive playing to fulfill the plan (Krause \& Pim, 2002, p. 261). 
FIBA Africa Champions Cup for Men is the greatest professional basketball competition for clubs, participating in it the champions of the leagues of the African countries (FIBA, 2002).

In (2016), FIBA Africa Champions Cup for Men took place in AlAhly club, Egypt. Ten teams were competing in this event: "Al -Ahly (Egypt) - Recreativo do Libolo (Angola) - AS Sale (Morocco) Kano Pillars (Nigeria) - Club Africain (Tunisia) - GS Petroliers (Algeria) - BEAC Basket (Cameroon) - Primeiro D'Agosto (Angola) - City Oilers (Uganda) - Nzui-Manto (Cameroon)" (FIBA, 2016a).

Al-Ahly club won its first-ever FIBA Africa Champions Cup title, which was a historic victory considering the fact that it was the first local Egyptian basketball club to win the trophy since Al Gezira win in 1996. This winning came as a surprise, especially after the FIBA official website posted the teams' statistics on points per game and total points, Al- Ahly team was placed the sixth, whereas Recreativo do Libolo came first and AS Sale got the second place. For the field goal shooting, Al- Ahly came fifth, whereas Recreativo do Libolo came fourth and AS Sale got the first place. Concerning the 2 point field goals, Al- Ahly came third, whereas Recreativo do Libolo came fourth and AS Sale got the first place. On the 3 point field goals, AlAhly team came fourth, whereas Recreativo do Libolo came third and AS Sale got the first place. While on free-throws Al- Ahly team came second, Recreativo do Libolo came first and AS Sale the six. On rebounds, Al- Ahly came second, Recreativo do Libolo fifth and AS Sale third. On blocks, Al-Ahly was first, whereas Recreativo do Libolo was ninth and AS Sale fifth. For Assists, Al-Ahly came fourth, Recreativo do Libolo third and AS Sale second. For Steals, Al-Ahly came seventh, Recreativo do Libolo fifth and AS Sale eighth. For Turn overs, Al- Ahly was eighth, Recreativo do Libolo tenth and AS Sale got first place. For Fouls, Al-Ahly came sixth, Recreativo do Libolo second and AS Sale sixth. For Minutes, AlAhly was third, Recreativo do Libolo sixth and AS Sale fifth. As for Double-doubles, Al-Ahly came fourth, Recreativo do Libolo second and AS Sale got third place. In view of these analyzes, we find that Al-Ahly club in the majority of the items holds back places, whereas Recreativo do Libolo and AS Sale hold front places (FIBA, 2016a; 2016b).

Therefore, the aim of this study was to identify the effect of transitions from offense to defense and vice versa on the result of FIBA Africa Champions Cup for men (2016) regarding the first three places. 


\section{Hypothesis:}

(1) There are statistically significant differences between transitions in the result of a team winning first place (Al-Ahly club) in favor of very quick transition offense and defense.

(2)There are statistically significant differences between transitions in the result of a team winning second place (Recreativo do Libolo club) in favor of very quick transition offense and defense.

(3) There are statistically significant differences between transitions in the result of a team winning third place (AS Sale club) in favor of very quick transition offense and defense.

(4)There are statistically significant differences between transitions in the results of the three teams coming at the three first places: (Al-Ahly club, Recreativo do Libolo club and AS Sale club) in favor of very quick transition offense and defense for Al-Ahly club.

\section{Methods:}

\subsection{Approach:}

The researcher used descriptive approach for its suitability to analyze basketball matches.

\subsection{Sample:}

The researcher intentionally approach used in selecting FIBA Africa Champions Cup for men (2016) as an example, choosing the first three places from ten teams by (30\%) and matches played by these first three teams, each team played seven matches viz (21) matches by (64\%) from the total of (33) matches.

\subsection{Procedures:}

- The researcher downloaded all matches of FIBA Africa Champions Cup for men (2016) from FIBA official website.

- The researcher conducted the pilot study on Classification (78) between (BEAC Basket vs Primeiro D'Agosto), Classification (5-6) between (GS Petroliers vs Club Africain), $3^{\text {rd }}$ Place between (Kano Pillars vs AS Sale) and Final between (Al Ahly vs Recreativo do Libolo) to check the analysis program, Utilius ${ }^{\circledR}$ vs advanced version (4.5.8) and to determine the classification of offensive transition is (1-3 seconds) very quick transition, (3-4 seconds) quick transition, 
(4-5 seconds) normal transition and (5-8 seconds) slow transition, and also to confirm that the classification of defensive transition is (zero second) very quick transition, (1-3 seconds) quick transition. Then the researcher presented it to experts (coaches who have at least ten years' experience in his field) who agreed to these divisions.

Notes (1): The standard in determining the speed of the transition is from the starting time of the offense (at the twenty fourth seconds) until the crossing of the midcourt line direct.

Notes (2): Some offense and defense without transition, such as in the case after timeout at the last two minutes in quarter four, foul and violation done in midcourt " Front area of the court", start quarter two, three and four if they pass the ball on " Front area of the court" and time of offense ended before crossing the midcourt line.

- Then the researcher designed the court using the program with cases (inside the basket with (1 point, 2 points, 3 points and 4 points) - out - cut - foul - violation - End - Failure) with classification of transitions, also quarters (q1- q2- q3-q4) and the kind of transition (offense-defense). Figure 1.

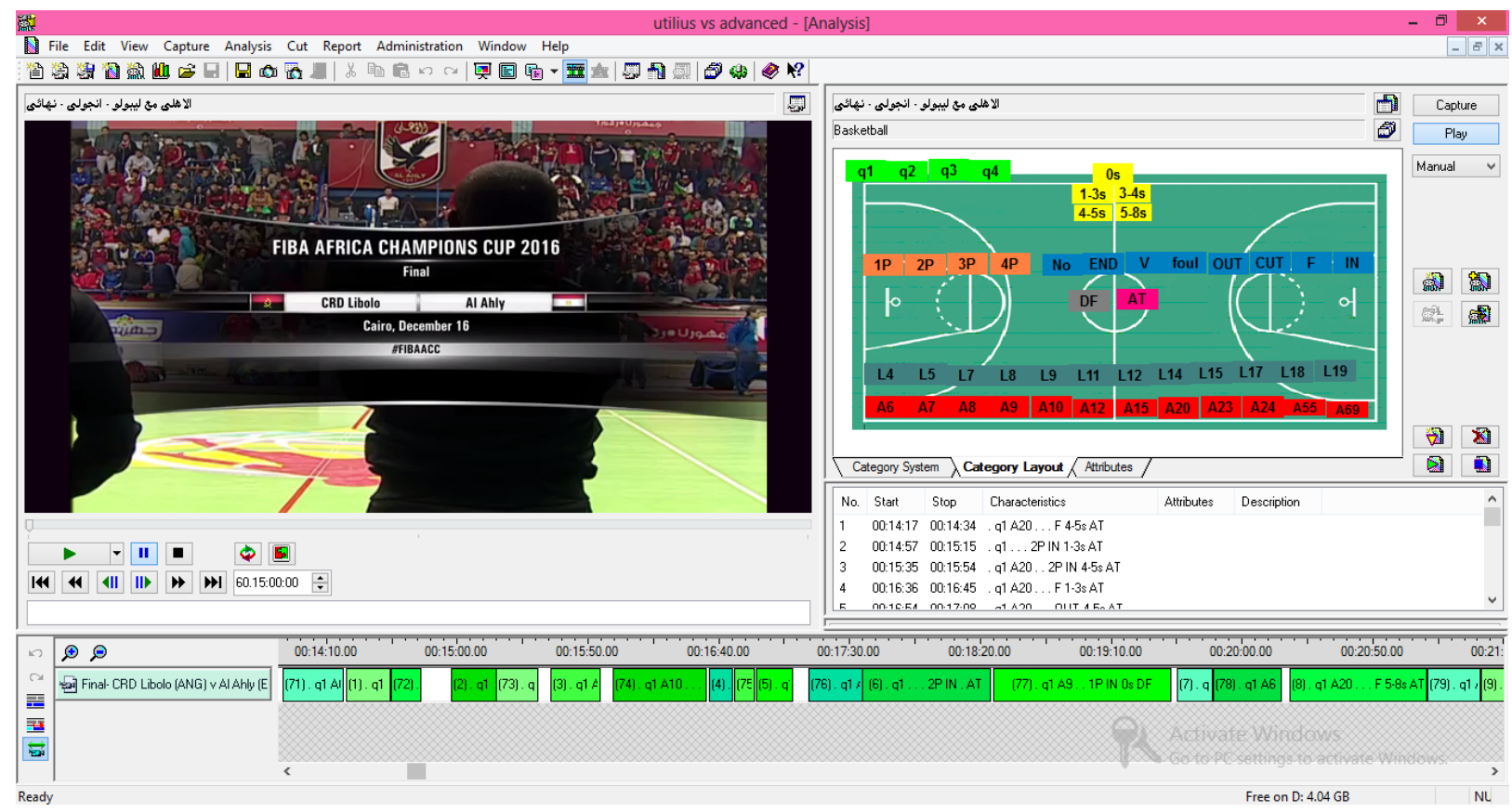

Figure 1. Picture to the court on the program with cases, classification of transition, also quarters and the kinds of transition 
- The time it took to analyze the matches for the pilot study (4 matches) was three weeks, from 2nd to 23rd February, 2017, and the first three places (21 matches) was three months, from March 7th to June 1st, 2017, with the total of 25 matches by $76 \%$, using analysis program Utilius ${ }^{\circledR}$ vs advanced version (4.5.8).

\subsection{Statistical Analysis:}

The researcher used IBM SPSS statistics version (24) to analyze all data. However before analyzing the data, she checked the normality of the sample by Shapiro-Wilk test to determine which statistics will use parametric or non- parametric, $\mathrm{p}$-value for Al-Ahly club at transition offense scored $(0.14,0.56,0.22,0.15,0.47)$, p-value for Recreativo do Libolo club at transition offense scored $(0.55,0.83$, $0.92,0.08,0.01)$ and $p$-value for AS Sale club at transition offense scored $(0.22,0.71,0.51,0.15,0.14) ; \mathrm{p}$-value for Al-Ahly club at transition defense scored $(0.30,0.06,0.16)$, $\mathrm{p}$-value for Recreativo do Libolo club at transition defense scored $(0.02,0.27,0.30)$, p-value for AS Sale club at transition defense scored $(0.61,0.45,0.40)$. From that, she showed that p-value sig. > o.o5, which means parametric statistics should be used "one way ANOVA test, Tukey HSD test" to compare all data.

\section{Result:}

Table 1. Presents the mean and Standard Deviation for the first three places (Al- Ahly club, Recreativo do Libolo club and AS Sale club) on transitions offense and transitions defense.

Table 1. Means and Standard Deviations for the first three places on the result in each transitions offense and defense

\begin{tabular}{lllll}
\hline \multicolumn{1}{c}{ Teams } & \multicolumn{1}{c}{ Variables } & $\boldsymbol{n}$ & $\boldsymbol{M}$ & SD \\
\hline $\begin{array}{llll}\text { Al- Ahly club on } \\
\text { offense }\end{array}$ & no transition & 7 & 4.42 & 3.25 \\
& one to three S T & 7 & 38.57 & 11.83 \\
& three to four S T & 7 & 7.85 & 3.89 \\
& four to five S T & 7 & 11.42 & 3.73 \\
& five to eight S T & 7 & 12.42 & 5.19 \\
$\begin{array}{l}\text { Recreativo do } \\
\begin{array}{l}\text { Libolo club on } \\
\text { offense }\end{array}\end{array}$ & no transition & 7 & 2.71 & 2.21 \\
& one to three S T & 7 & 41.14 & 14.39 \\
& three to four S T & 7 & 12.57 & 6.62 \\
\hline
\end{tabular}




\begin{tabular}{|c|c|c|c|c|}
\hline \multirow{7}{*}{$\begin{array}{l}\text { AS Sale club on } \\
\text { offense }\end{array}$} & four to five S T & 7 & 22.28 & 9.08 \\
\hline & five to eight $S \mathrm{~T}$ & 7 & 4.00 & 2.88 \\
\hline & no transition & 7 & 3.57 & 2.93 \\
\hline & one to three $\mathrm{S} T$ & 7 & 51.14 & 11.23 \\
\hline & three to four S T & 7 & 13.42 & 5.47 \\
\hline & four to five $S T$ & 7 & 8.71 & 5.21 \\
\hline & five to eight $S \mathrm{~T}$ & 7 & 5.00 & 5.97 \\
\hline \multirow{3}{*}{$\begin{array}{l}\text { Al- Ahly club on } \\
\text { defense }\end{array}$} & no transition & 7 & 1.42 & 1.39 \\
\hline & zero S T & 7 & 27.71 & 7.99 \\
\hline & one to three S T & 7 & 14.71 & 6.60 \\
\hline \multirow{3}{*}{$\begin{array}{l}\text { Recreativo do } \\
\text { Libolo club on } \\
\text { defense }\end{array}$} & no transition & 7 & 3.00 & .57 \\
\hline & zero S T & 7 & 30.85 & 5.04 \\
\hline & one to three S T & 7 & 10.14 & 3.38 \\
\hline \multirow{3}{*}{$\begin{array}{l}\text { As Sale club on } \\
\text { defense }\end{array}$} & no transition & 7 & 3.85 & 2.41 \\
\hline & zero S T & 7 & 33.57 & 4.92 \\
\hline & one to three $\mathrm{S} T$ & 7 & 8.28 & 2.98 \\
\hline
\end{tabular}

Table 2. Shows that there were a significant effect between five types of transitions offense (no transition, one to three seconds transition, three to four seconds transition, four to five seconds transition and five to eight seconds transition) on the result of basketball matches at $\mathrm{p}<0.05$ level for the first three clubs, Al- Ahly club $[\mathrm{F}(4,30)=31.24, \mathrm{p}=0.00]$, Recreativo do Libolo club $[\mathrm{F}(4$, $30)=25.28, \mathrm{p}=0.00]$ and AS Sale club $[\mathrm{F}(4,30)=60.33, \mathrm{p}=0.00]$.

Table 2. Also shows that there were a significant effect between three types of transitions defense (no transition, zero second transition and one to three seconds transition) on the result of basketball matches at $\mathrm{p}<0.05$ level for the first three clubs, Al-Ahly club $[\mathrm{F}(2,18)=33.15, \mathrm{p}=0.00]$, Recreativo do Libolo club $[\mathrm{F}(2,18)$ $=117.91, p=0.00]$ and AS Sale club $[F(2,18)=138.37, p=0.00]$.

Table 2. One way ANOVA for the first three places on the result in each transitions offense and defense

\begin{tabular}{ccccccc}
\hline Teams & Variables & $d f$ & SS & MS & $\boldsymbol{F}$ & $\boldsymbol{P}$ \\
\hline Al- Ahly club & Between Groups & 4 & 5164.17 & 1291.04 & 31.24 & .00 \\
\hline
\end{tabular}




\begin{tabular}{|c|c|c|c|c|c|c|}
\hline \multirow[t]{2}{*}{ on offense } & Within Groups & 30 & 1239.71 & 41.32 & & \\
\hline & Total & 34 & 6403.88 & & & \\
\hline \multirow{3}{*}{$\begin{array}{l}\text { Recreativo do } \\
\text { Libolo club on } \\
\text { offense }\end{array}$} & Between Groups & 4 & 7017.25 & 1754.31 & 25.28 & .00 \\
\hline & Within Groups & 30 & 2081.42 & 69.38 & & \\
\hline & Total & 34 & 9098.68 & & & \\
\hline \multirow{3}{*}{$\begin{array}{l}\text { AS Sale club } \\
\text { on offense }\end{array}$} & Between Groups & 4 & 10986.45 & 2746.61 & 60.33 & .00 \\
\hline & Within Groups & 30 & 1365.71 & 45.52 & & \\
\hline & Total & 34 & 12352.17 & & & \\
\hline \multirow{3}{*}{$\begin{array}{l}\text { Al- Ahly club } \\
\text { on defense }\end{array}$} & Between Groups & 2 & 2418.38 & 1209.19 & 33.15 & .00 \\
\hline & Within Groups & 18 & 656.57 & 36.47 & & \\
\hline & Total & 20 & 3074.95 & & & \\
\hline \multirow{3}{*}{$\begin{array}{l}\text { Recreativo do } \\
\text { Libolo club on } \\
\text { defense }\end{array}$} & Between Groups & 2 & 2930.95 & 1465.47 & 117.91 & .00 \\
\hline & Within Groups & 18 & 223.71 & 12.42 & & \\
\hline & Total & 20 & 3154.66 & & & \\
\hline \multirow{3}{*}{$\begin{array}{l}\text { As Sale club } \\
\text { on defense }\end{array}$} & Between Groups & 2 & 3597.81 & 1798.90 & 138.37 & .00 \\
\hline & Within Groups & 18 & 234.00 & 13.00 & & \\
\hline & Total & 20 & 3831.81 & & & \\
\hline
\end{tabular}

Table 3. Shows that the post hoc comparisons using the Tukey HSD test indicated that the mean score for one to three seconds transition for Al- Ahly club on offense $(\mathrm{M}=38.57, \mathrm{SD}=11.83)$ was significantly different from the no transition $(\mathrm{M}=4.42, \mathrm{SD}=3.25)$, three to four seconds transition $(\mathrm{M}=7.85, \mathrm{SD}=3.89)$, four to five seconds transition $(\mathrm{M}=11.42, \mathrm{SD}=3.73)$, and five to eight seconds transition ( $\mathrm{M}=12.42, \mathrm{SD}=5.19)$. However, the other transitions (no transition, three to four seconds transition, four to five seconds transition and five to eight seconds transition) did not significantly differ from each other.

Table 3. Shows that the post hoc comparisons using the Tukey HSD test indicated that the mean score for zero second transition for Al- Ahly club on defense $(\mathrm{M}=27.71, \mathrm{SD}=7.99)$ was significantly different from the no transition $(\mathrm{M}=1.42, \mathrm{SD}=1.39)$, and one to three seconds transition $(\mathrm{M}=14.71, \mathrm{SD}=6.60)$. Also, the other transitions (no transition and one to three seconds transition) were not the same, but this significantly differ in favor of zero second transition with a mean score greater than other transition. 
Table 3. Tukey HSD test for Al-Ahly club on the result in each transitions offense and defense

\begin{tabular}{|c|c|c|c|c|c|}
\hline Variable & (I) transitions & (J) transitions & $M D(I-J)$ & Std. Error & $P$ \\
\hline \multirow{20}{*}{$\begin{array}{l}\text { Al- Ahly club on } \\
\text { offense }\end{array}$} & no transition & one to three $\mathrm{S} \mathrm{T}$ & $-34.14-^{*}$ & 3.43 & .00 \\
\hline & & three to four $\mathrm{S} \mathrm{T}$ & $-3.42-$ & 3.43 & .85 \\
\hline & & four to five S T & $-7.00-$ & 3.43 & .27 \\
\hline & & five to eight S T & $-8.00-$ & 3.43 & .16 \\
\hline & one to three S T & no transition & $34.14^{*}$ & 3.43 & .00 \\
\hline & & three to four $\mathrm{S} T$ & $30.71^{*}$ & 3.43 & .00 \\
\hline & & four to five $S T$ & $27.14^{*}$ & 3.43 & .00 \\
\hline & & five to eight $S \mathrm{~T}$ & $26.14^{*}$ & 3.43 & .00 \\
\hline & three to four S T & no transition & 3.42 & 3.43 & .85 \\
\hline & & one to three S T & $-30.71-^{*}$ & 3.43 & .00 \\
\hline & & four to five $S T$ & $-3.57-$ & 3.43 & .83 \\
\hline & & five to eight $\mathrm{S} T$ & $-4.57-$ & 3.43 & .67 \\
\hline & four to five $S \mathrm{~T}$ & no transition & 7.00 & 3.43 & .27 \\
\hline & & one to three S T & $-27.14-^{*}$ & 3.43 & .00 \\
\hline & & three to four S T & 3.57 & 3.43 & .83 \\
\hline & & five to eight $S T$ & $-1.00-$ & 3.43 & .99 \\
\hline & five to eight S T & no transition & 8.00 & 3.43 & .16 \\
\hline & & one to three S T & $-26.14-^{*}$ & 3.43 & .00 \\
\hline & & three to four S T & 4.57 & 3.43 & .67 \\
\hline & & four to five S T & 1.00 & 3.43 & .99 \\
\hline \multirow{6}{*}{$\begin{array}{l}\text { Al- Ahly club on } \\
\text { defense }\end{array}$} & no transition & zero S T & $-26.28-^{*}$ & 3.22 & .00 \\
\hline & & one to three $\mathrm{S} \mathrm{T}$ & $-13.28-^{*}$ & 3.22 & .00 \\
\hline & zero S T & no transition & $26.28^{*}$ & 3.22 & .00 \\
\hline & & one to three S T & $13.00^{*}$ & 3.22 & .00 \\
\hline & one to three $\mathrm{S} \mathrm{T}$ & no transition & $13.28^{*}$ & 3.22 & .00 \\
\hline & & Zero S T & $-13.00-^{*}$ & 3.22 & .00 \\
\hline
\end{tabular}

*. The mean difference is significant at the 0.05 level.

$\mathrm{S} \mathrm{T}$ for second transition 
Table 4. Shows that the post hoc comparisons using the Tukey HSD test indicated that the mean score for one to three seconds transition for Recreativo do Libolo club on offense $(\mathrm{M}=41.14, \mathrm{SD}$ $=14.39)$ was significantly different from the no transition $(\mathrm{M}=2.71$, $\mathrm{SD}=2.21)$, three to four seconds transition $(\mathrm{M}=12.57, \mathrm{SD}=6.62)$, four to five seconds transition $(\mathrm{M}=22.28, \mathrm{SD}=9.08)$, and five to eight seconds transition $(\mathrm{M}=4.00, \mathrm{SD}=2.88)$. And also four to five seconds transition for Recreativo do Libolo club offense was significantly different from the no transition, one to three seconds transition, and five to eight seconds transition. However, the other transitions (no transition, three to four seconds transition, and five to eight seconds transition) did not significantly differ from each other.

Table 4. Also shows that post hoc comparisons using the Tukey HSD test indicated that the mean score for zero second transition for Recreativo do Libolo club on defense $(M=30.85$, $S D=5.04)$ was significantly different from the no transition $(\mathrm{M}=3.00, \mathrm{SD}=0.57)$, one to three seconds transition $(\mathrm{M}=10.14, \mathrm{SD}=3.38)$. Also, the other transitions (no transition, one to three seconds transition) were significantly different from each other, but in this case it is different in favor of zero second transition with a mean score greater than other transitions.

Table 4. Tukey HSD test for Recreativo do Libolo club on the result in each transitions offense and defense

\begin{tabular}{|c|c|c|c|c|c|}
\hline Variable & (I) transitions & (J) transitions & $M D(I-J)$ & Std. Error & $P$ \\
\hline \multirow{12}{*}{$\begin{array}{l}\text { Recreativo do } \\
\text { Libolo club on } \\
\text { offense }\end{array}$} & no transition & one to three S T & $-38.42-^{*}$ & 4.45 & .00 \\
\hline & & three to four $\mathrm{S} T$ & $-9.85-$ & 4.45 & .20 \\
\hline & & four to five S T & $-19.577^{*}$ & 4.45 & .00 \\
\hline & & five to eight $S \mathrm{~T}$ & -1.28 & 4.45 & .99 \\
\hline & one to three $\mathrm{S} T$ & no transition & $38.42^{*}$ & 4.45 & .00 \\
\hline & & three to four $S \mathrm{~T}$ & $28.57^{*}$ & 4.45 & .00 \\
\hline & & four to five S T & $18.85^{*}$ & 4.45 & .00 \\
\hline & & five to eight $\mathrm{S} T$ & $37.14^{*}$ & 4.45 & .00 \\
\hline & three to four $\mathrm{S} T$ & no transition & 9.85 & 4.45 & .20 \\
\hline & & one to three $\mathrm{S} T$ & $-28.577^{*}$ & 4.45 & .00 \\
\hline & & four to five S T & $-9.71-$ & 4.45 & .21 \\
\hline & & five to eight $S T$ & 8.57 & 4.45 & .32 \\
\hline
\end{tabular}




\begin{tabular}{|c|c|c|c|c|c|}
\hline & four to five S T & no transition & $19.57^{*}$ & 4.45 & .00 \\
\hline & & one to three $S \mathrm{~T}$ & $-18.85-^{*}$ & 4.45 & .00 \\
\hline & & three to four $S T$ & 9.71 & 4.45 & .21 \\
\hline & & five to eight $S T$ & $18.28^{*}$ & 4.45 & .00 \\
\hline & five to eight S T & no transition & 1.28 & 4.45 & .99 \\
\hline & & one to three $\mathrm{S} T$ & $-37.144^{*}$ & 4.45 & .00 \\
\hline & & three to four $S \mathrm{~T}$ & $-8.57-$ & 4.45 & .32 \\
\hline & & four to five S T & $-18.28-^{*}$ & 4.45 & .00 \\
\hline Recreativo do & no transition & zero transition & $-27.85-^{*}$ & 1.88 & .00 \\
\hline defense & & one to three S T & $-7.14-^{*}$ & 1.88 & .00 \\
\hline & zero S T & no transition & $27.85^{*}$ & 1.88 & .00 \\
\hline & & one to three S T & $20.71^{*}$ & 1.88 & .00 \\
\hline & one to three $\mathrm{S} T$ & no transition & $7.14^{*}$ & 1.88 & .00 \\
\hline & & zero S T & $-20.71-^{*}$ & 1.88 & .00 \\
\hline
\end{tabular}

Table 5. Shows that the post hoc comparisons using the Tukey HSD test indicated that the mean score for one to three seconds transition for AS Sale club offense $(\mathrm{M}=51.14, \mathrm{SD}=11.23)$ was significantly different from the no transition $(\mathrm{M}=3.57, \mathrm{SD}=2.93)$, three to four seconds transition $(\mathrm{M}=13.42, \mathrm{SD}=5.47)$, four to five seconds transition $(\mathrm{M}=8.71, \mathrm{SD}=5.21)$, and five to eight seconds transition $(\mathrm{M}=5.00, \mathrm{SD}=5.97)$. However, the other transitions (no transition, three to four seconds transition, four to five seconds transition and five to eight seconds transition) did not significantly differ from each other.

Table 5. Also shows that the post hoc comparisons using the Tukey HSD test indicated that the mean score for zero second transition for AS Sale club defense $(\mathrm{M}=33.57, \mathrm{SD}=4.92)$ was significantly different from the no transition $(\mathrm{M}=3.85, \mathrm{SD}=2.41)$, and one to three seconds transition $(\mathrm{M}=8.28, \mathrm{SD}=2.98)$. Also, the other transitions (no transition and one to three seconds transition) were significantly different from each other, but this significant difference was in favor of zero second transition with a mean score greater than other transitions. 
Table 5. Tukey HSD test for AS Sale club on the result in each transitions offense and defense

\begin{tabular}{|c|c|c|c|c|c|}
\hline Variable & (I) transitions & (J) transitions & $M D(I-J)$ & Std. Error & $P$ \\
\hline \multirow{20}{*}{$\begin{array}{l}\text { AS Sale Club on } \\
\text { offense }\end{array}$} & no transition & one to three $\mathrm{ST}$ & $-47.57-^{*}$ & 3.60 & .00 \\
\hline & & three to four $\mathrm{S} T$ & $-9.85-$ & 3.60 & .07 \\
\hline & & four to five S T & $-5.14-$ & 3.60 & .61 \\
\hline & & five to eight $S T$ & $-1.42-$ & 3.60 & .99 \\
\hline & one to three $\mathrm{S} T$ & no transition & $47.57^{*}$ & 3.60 & .00 \\
\hline & & three to four $\mathrm{S} T$ & $37.71^{*}$ & 3.60 & .00 \\
\hline & & four to five S T & $42.42^{*}$ & 3.60 & .00 \\
\hline & & five to eight $S T$ & $46.14^{*}$ & 3.60 & .00 \\
\hline & three to four S T & no transition & 9.85 & 3.60 & .07 \\
\hline & & one to three $\mathrm{S} T$ & $-37.71-^{*}$ & 3.60 & .00 \\
\hline & & four to five S T & 4.71 & 3.60 & .68 \\
\hline & & five to eight $S \mathrm{~T}$ & 8.42 & 3.60 & .16 \\
\hline & four to five $S T$ & no transition & 5.14 & 3.60 & .61 \\
\hline & & one to three $\mathrm{S} T$ & $-42.42-^{*}$ & 3.60 & .00 \\
\hline & & three to four $S T$ & $-4.71-$ & 3.60 & .68 \\
\hline & & five to eight $S T$ & 3.71 & 3.60 & .84 \\
\hline & five to eight $\mathrm{S} T$ & no transition & 1.42 & 3.60 & .99 \\
\hline & & one to three $\mathrm{S} T$ & $-46.14-^{*}$ & 3.60 & .00 \\
\hline & & three to four $\mathrm{S} T$ & $-8.42-$ & 3.60 & .16 \\
\hline & & four to five S T & $-3.71-$ & 3.60 & .84 \\
\hline \multirow{6}{*}{$\begin{array}{l}\text { As Sale club on } \\
\text { defense }\end{array}$} & no transition & zero transition & $-29.71-^{*}$ & 1.92 & .00 \\
\hline & & one to three $\mathrm{S} T$ & $-4.42-$ & 1.92 & .08 \\
\hline & zero S T & no transition & $29.71^{*}$ & 1.92 & .00 \\
\hline & & one to three $\mathrm{S} T$ & $25.28^{*}$ & 1.92 & .00 \\
\hline & one to three S T & no transition & 4.42 & 1.92 & .08 \\
\hline & & zero S T & $-25.28-^{*}$ & 1.92 & .00 \\
\hline
\end{tabular}

*. The mean difference is significant at the 0.05 level.

$\mathrm{S} \mathrm{T}$ for second transition 
These results on (tables 1, 2, 3, 4\&5) show that p-value sig. < 0.05 in one way ANOVA Test, which means there are a statistically significant differences between transitions offense for each club (AlAhly club, Recreativo do Libolo club and AS Sale club) in the number of points in favor of very quick transition as the mean of one to three seconds transition offense on each club is greater than the mean in the other transitions.

These results suggest that moving very quickly to as transition offense has an effect on the result (number of points scored). To be more specific, our result suggests that when the team follows the very quick transition on offense technique, it gets to score more points. However, it should be noted that the transition offense must be executed very quickly (one to three seconds) in order to achieve an effect. Other transitions (no transition, three to four seconds, four to five seconds and five to eight seconds) seem they do not significantly increase the number of points scored.

These results on tables $(1,2,3,4 \& 5)$ also show that p-value sig. $<0.05$ in one way ANOVA Test, which means there are a statistically significant differences between transitions defense for each club (AlAhly club, Recreativo do Libolo club and AS Sale club) in the number of recurrences in preventing scoring points in favor of very quick transition, for the mean of zero second transition defense on each club greater than the mean in the other transitions.

These results suggest that moving to a very quick transition defense has an effect on the result (in the number of recurrences in preventing scoring points). To be more specific, our result suggests that when the team used a very quick transition technique on defense, it will be more effective in preventing scoring points against it. However, it should be noted that the transition defense must be executed very quickly (zero second) in order to achieve an effect.

Table 6. shows that there were significant differences between the first three places on transitions offense at basketball matches at $\mathrm{p}<0.05$ level for the five types of transitions offense, no transition $[\mathrm{F}(2,18)=0.63, \mathrm{p}=0.53]$, one to three seconds transition $[\mathrm{F}(2,18)$ $=1.95, \mathrm{p}=0.17]$, three to four seconds transition $[\mathrm{F}(2,18)=2.12, \mathrm{p}=$ $0.14]$, four to five seconds transition $[\mathrm{F}(2,18)=8.75, \mathrm{p}=0.00]$ and five to eight seconds transition $[\mathrm{F}(2,18)=6.27, \mathrm{p}=0.00]$ for the first three clubs. 
Table 6. Also shows there were significant differences between the first three places on transitions defense at basketball matches at $\mathrm{p}<0.05$ level for the three types of transitions defense, no transition $[\mathrm{F}(2,18)=3.93, \mathrm{p}=0.03]$, zero second transition $[\mathrm{F}(2,18)=1.58, \mathrm{p}=$ $0.23]$ and one to three seconds transition $[F(2,18)=3.59, p=0.04]$ for the first three clubs.

Table 6. One way ANOVA for the result on each transition offense and defense for the first three places

\begin{tabular}{|c|c|c|c|c|c|c|}
\hline Variables & & $d f$ & $S S$ & MS & $F$ & $P$ \\
\hline \multirow{3}{*}{$\begin{array}{l}\text { no transition } \\
\text { offense }\end{array}$} & Between Groups & 2 & 10.28 & 5.14 & .63 & .53 \\
\hline & Within Groups & 18 & 144.85 & 8.04 & & \\
\hline & Total & 20 & 155.14 & & & \\
\hline \multirow{3}{*}{$\begin{array}{l}\text { one to three S T } \\
\text { offense }\end{array}$} & Between Groups & 2 & 617.52 & 308.76 & 1.95 & .17 \\
\hline & Within Groups & 18 & 2839.42 & 157.74 & & \\
\hline & Total & 20 & 3456.95 & & & \\
\hline \multirow{3}{*}{$\begin{array}{l}\text { three to four S T } \\
\text { offense }\end{array}$} & Between Groups & 2 & 126.00 & 63.00 & 2.12 & .14 \\
\hline & Within Groups & 18 & 534.28 & 29.68 & & \\
\hline & Total & 20 & 660.28 & & & \\
\hline \multirow{3}{*}{$\begin{array}{l}\text { four to five S T } \\
\text { offense }\end{array}$} & Between Groups & 2 & 722.00 & 361.00 & 8.75 & .00 \\
\hline & Within Groups & 18 & 742.57 & 41.25 & & \\
\hline & Total & 20 & 1464.57 & & & \\
\hline \multirow{3}{*}{$\begin{array}{l}\text { five to eight } \mathrm{ST} \\
\text { offense }\end{array}$} & Between Groups & 2 & 296.85 & 148.42 & 6.27 & .00 \\
\hline & Within Groups & 18 & 425.71 & 23.65 & & \\
\hline & Total & 20 & 722.57 & & & \\
\hline \multirow{3}{*}{$\begin{array}{l}\text { no transition } \\
\text { defense }\end{array}$} & Between Groups & 2 & 21.23 & 10.61 & 3.93 & .03 \\
\hline & Within Groups & 18 & 48.57 & 2.69 & & \\
\hline & Total & 20 & 69.81 & & & \\
\hline \multirow[t]{3}{*}{ zero S T defense } & Between Groups & 2 & 120.28 & 60.14 & 1.58 & .23 \\
\hline & Within Groups & 18 & 682.00 & 37.88 & & \\
\hline & Total & 20 & 802.28 & & & \\
\hline
\end{tabular}




\begin{tabular}{|c|c|c|c|c|c|c|}
\hline \multirow{3}{*}{$\begin{array}{l}\text { one to three S T } \\
\text { defense }\end{array}$} & Between Groups & 2 & 153.23 & 76.61 & 3.59 & .04 \\
\hline & Within Groups & 18 & 383.71 & 21.31 & & \\
\hline & Total & 20 & 536.95 & & & \\
\hline
\end{tabular}

Table 7. Shows that the post hoc comparisons using the Tukey HSD test indicated that the mean score for Recreativo do Libolo club on offense for four to five seconds transition $(\mathrm{M}=22.28, \mathrm{SD}=9.08)$ was significantly different from $\mathrm{Al}-$ Ahly club $(\mathrm{M}=11.42, \mathrm{SD}=$ 3.73) and AS Sale club $(M=8.71, S D=5.21)$. However, the other clubs (Al- Ahly club and AS Sale club) did not significantly differ from each other. Also the Tukey HSD test indicated that the mean score for $\mathrm{Al}$-Ahly club on offense for five to eight seconds transition $(\mathrm{M}=12.42, \mathrm{SD}=5.19)$ was significantly different from Recreativo do Libolo club $(\mathrm{M}=4.00, \mathrm{SD}=2.88)$ and AS Sale club $(\mathrm{M}=5.00$, $\mathrm{SD}=5.97$ ) However, the other clubs (Recreativo do Libolo club and AS Sale club) did not significantly differ from each other.

Table 7. Tukey HSD test for the result in each transition offense for the first three places

\begin{tabular}{|c|c|c|c|c|c|}
\hline Variable & (I) teams & (J) teams & $M D(I-J)$ & Std. Error & $P$ \\
\hline \multirow[t]{6}{*}{$\begin{array}{l}\text { no transition } \\
\text { offense }\end{array}$} & Al-Ahly club & $\begin{array}{l}\text { Recreativo do } \\
\text { Libolo club }\end{array}$ & 1.71 & 1.51 & .50 \\
\hline & & As Sale club & .85 & 1.51 & .84 \\
\hline & $\begin{array}{l}\text { Recreativo do } \\
\text { Libolo club }\end{array}$ & Al-Ahly club & $-1.71-$ & 1.51 & .50 \\
\hline & & As Sale club & $-.85-$ & 1.51 & .84 \\
\hline & As Sale club & Al-Ahly club & $-.85-$ & 1.51 & .84 \\
\hline & & $\begin{array}{l}\text { Recreativo do } \\
\text { Libolo club }\end{array}$ & .85 & 1.51 & .84 \\
\hline \multirow[t]{6}{*}{$\begin{array}{l}\text { one to three S T } \\
\text { offense }\end{array}$} & Al-Ahly club & $\begin{array}{l}\text { Recreativo do } \\
\text { Libolo club }\end{array}$ & $-2.57-$ & 6.71 & .92 \\
\hline & & As Sale club & $-12.57-$ & 6.71 & .17 \\
\hline & $\begin{array}{l}\text { Recreativo do } \\
\text { Libolo club }\end{array}$ & Al-Ahly club & 2.57 & 6.71 & .92 \\
\hline & & As Sale club & $-10.00-$ & 6.71 & .31 \\
\hline & As Sale club & Al-Ahly club & 12.57 & 6.71 & .17 \\
\hline & & $\begin{array}{l}\text { Recreativo do } \\
\text { Libolo club }\end{array}$ & 10.00 & 6.71 & .31 \\
\hline
\end{tabular}




\begin{tabular}{|c|c|c|c|c|c|}
\hline \multirow[t]{6}{*}{$\begin{array}{l}\text { three to four S T } \\
\text { offense }\end{array}$} & Al-Ahly club & $\begin{array}{l}\text { Recreativo do } \\
\text { Libolo club }\end{array}$ & $-4.71-$ & 2.91 & .26 \\
\hline & & As Sale club & $-5.57-$ & 2.91 & .16 \\
\hline & $\begin{array}{l}\text { Recreativo do } \\
\text { Libolo club }\end{array}$ & Al-Ahly club & 4.71 & 2.91 & .26 \\
\hline & & As Sale club & $-.85-$ & 2.91 & .95 \\
\hline & As Sale club & Al-Ahly club & 5.57 & 2.91 & .16 \\
\hline & & $\begin{array}{l}\text { Recreativo do } \\
\text { Libolo club }\end{array}$ & .85 & 2.91 & .95 \\
\hline \multirow[t]{6}{*}{$\begin{array}{l}\text { four to five } S T \\
\text { offense }\end{array}$} & Al-Ahly club & $\begin{array}{l}\text { Recreativo do } \\
\text { Libolo club }\end{array}$ & $-10.85-^{*}$ & 3.43 & .01 \\
\hline & & As Sale club & 2.71 & 3.43 & .71 \\
\hline & $\begin{array}{l}\text { Recreativo do } \\
\text { Libolo club }\end{array}$ & Al-Ahly club & $10.85^{*}$ & 3.43 & .01 \\
\hline & & As Sale club & $13.57^{\star}$ & 3.43 & .00 \\
\hline & As Sale club & Al-Ahly club & $-2.71-$ & 3.43 & .71 \\
\hline & & $\begin{array}{l}\text { Recreativo do } \\
\text { Libolo club }\end{array}$ & $-13.57-{ }^{*}$ & 3.43 & .00 \\
\hline \multirow[t]{6}{*}{$\begin{array}{l}\text { five to eight } S \mathrm{~T} \\
\text { offense }\end{array}$} & Al-Ahly club & $\begin{array}{l}\text { Recreativo do } \\
\text { Libolo club }\end{array}$ & $8.42^{*}$ & 2.59 & .01 \\
\hline & & As Sale club & $7.42^{*}$ & 2.59 & .02 \\
\hline & $\begin{array}{l}\text { Recreativo do } \\
\text { Libolo club }\end{array}$ & Al-Ahly club & $-8.42-^{*}$ & 2.59 & .01 \\
\hline & & As Sale club & $-1.00-$ & 2.59 & .92 \\
\hline & As Sale club & Al-Ahly club & $-7.42-^{*}$ & 2.59 & .02 \\
\hline & & $\begin{array}{l}\text { Recreativo do } \\
\text { Libolo club }\end{array}$ & 1.00 & 2.59 & .92 \\
\hline
\end{tabular}

*. The mean difference is significant at the 0.05 level.

$\mathrm{S} \mathrm{T}$ for second transition

These results on tables (6\&7) also show that p-value sig. $<0.05$ in one way ANOVA Test, which means there are a statistically significant differences between the first three places (Al- Ahly club, Recreativo do Libolo club and AS Sale club) for transitions offense in the number of points in favor of normal transition for Recreativo do Libolo club, as the mean of four to five seconds transition offense greater than the mean of five to eight seconds transition.

Table 8. Shows that the post hoc comparisons using the Tukey HSD test indicated that the mean score for Al- Ahly club on defense for no transition $(\mathrm{M}=1.42, \mathrm{SD}=1.39)$ was significantly different from AS Sale club $(\mathrm{M}=3.85, \mathrm{SD}=2.41)$. However, the other club 
(Recreativo do Libolo club) did not significantly differ from $\mathrm{Al}$ Ahly club and AS Sale club. Also the Tukey HSD test indicated that the mean score for Al-Ahly club on defense for one to three seconds transition $(\mathrm{M}=14.71, \mathrm{SD}=6.60)$ was significantly different from AS Sale club $(\mathrm{M}=8.28, \mathrm{SD}=2.98)$. However, the other club (Recreativo do Libolo club) did not significantly differ from Al-Ahly club and AS Sale club.

Table 8. Tukey HSD test for the result in each transition defense for the first three places

\begin{tabular}{|c|c|c|c|c|c|}
\hline Variable & (I) teams & $(J)$ teams & $M D(I-J)$ & Std. Error & $P$ \\
\hline \multirow[t]{6}{*}{ no transition defense } & Al-Ahly club & $\begin{array}{l}\text { Recreativo do } \\
\text { Libolo club }\end{array}$ & $-1.57-$ & .87 & .20 \\
\hline & & As Sale club & $-2.42-^{*}$ & .87 & .03 \\
\hline & $\begin{array}{l}\text { Recreativo do } \\
\text { Libolo club }\end{array}$ & Al-Ahly club & 1.57 & .87 & .20 \\
\hline & & As Sale club & $-.85-$ & .87 & .60 \\
\hline & As Sale club & Al-Ahly club & $2.42^{*}$ & .87 & .03 \\
\hline & & $\begin{array}{l}\text { Recreativo do } \\
\text { Libolo club }\end{array}$ & .85 & .87 & .60 \\
\hline \multirow[t]{6}{*}{ zero S T defense } & Al-Ahly club & $\begin{array}{l}\text { Recreativo do } \\
\text { Libolo club }\end{array}$ & $-3.14-$ & 3.29 & .61 \\
\hline & & As Sale club & $-5.85-$ & 3.29 & .20 \\
\hline & $\begin{array}{l}\text { Recreativo do } \\
\text { Libolo club }\end{array}$ & Al-Ahly club & 3.14 & 3.29 & .61 \\
\hline & & As Sale club & $-2.71-$ & 3.29 & .69 \\
\hline & As Sale club & Al-Ahly club & 5.85 & 3.29 & .20 \\
\hline & & $\begin{array}{l}\text { Recreativo do } \\
\text { Libolo club }\end{array}$ & 2.71 & 3.29 & .69 \\
\hline \multirow[t]{6}{*}{$\begin{array}{l}\text { one to three S T } \\
\text { defense }\end{array}$} & Al-Ahly club & $\begin{array}{l}\text { Recreativo do } \\
\text { Libolo club }\end{array}$ & 4.57 & 2.46 & .18 \\
\hline & & As Sale club & $6.42^{*}$ & 2.46 & .04 \\
\hline & $\begin{array}{l}\text { Recreativo do } \\
\text { Libolo club }\end{array}$ & Al-Ahly club & $-4.57-$ & 2.46 & .18 \\
\hline & & As Sale club & 1.85 & 2.46 & .73 \\
\hline & As Sale club & Al-Ahly club & $-6.42-^{*}$ & 2.46 & .04 \\
\hline & & $\begin{array}{l}\text { Recreativo do } \\
\text { Libolo club }\end{array}$ & $-1.85-$ & 2.46 & .73 \\
\hline
\end{tabular}


These results on tables $(6 \& 8)$ also show that p-value sig. $<0.05$ in one way ANOVA Test which means there are a statistically significant differences between the first three places (Al- Ahly club, Recreativo do Libolo club and AS Sale club) on transitions defense in the number of recurrences in preventing scoring points in favor of quick transition for Al-Ahly club, as the mean of one to three seconds transition defense is greater than the mean of no transition.

\section{Discussion:}

The main findings indicate that the very quick transition (one to three seconds transition) in the offense for the first three places (AlAhly club, Recreativo do Libolo club and AS Sale club) had a positive effect on the result which helped to get and increase the number of points scored.

These findings are consistent with "Ola Hassan (2000), Amin Hosny (2008), Tamer Monier (2008), Abdul Redha Mohammed (2013) and David Cárdenas et al. (2015)" in their researches, suggesting that using fast break or quick transition in offense in basketball matches plays a big role in winning (Hassan, 2000; Hosny, 2008; Monier, 2008; Mohammed, 2013; Cárdenas et al., 2015) .

Very quick transition offense "fast break" can produce an easy score. Moving it up the floor quickly puts a lot of pressure on the defense (Swope, 2012, p. 54).

Jon Oliver (2004) Indicates that the very quick transition offense "helps scoring quick and easy baskets before an opponent can adequately set up a defense, it is most exciting elements of basketball that helps to get a quick score" (Oliver, 2004, p. 97-99).

The teams who master a very quick offensive transition have a big chance to improve their scores, the transition also has a psychological effect on the teams by giving them a greater incentive and on the other hand reduces the morale of the opposing teams (Mohammed, 2013, p. 394).

Bob Cousy (2002) said that the very quick transition "is the ultimate offensive weapon because it puts extreme pressure on your opponents and many times will affect their offensive tempo" (Krause \& Pim, 2002, p. 261). 
what the results show evidently is that the very quick transition (zero second transition) in defense for the first three places (Al- Ahly club, Recreativo do Libolo club and AS Sale club) had positive effect on the result, helping in protecting and preventing opponent teams from scoring points, this means that the very quick defense transition is more effective on obstructing the attack and making it ineffective which has a direct reflection on the results of the matches.

These findings are consistent with "Miguel Angel Gómez et al. (2008) and Miguel Angel Gómez et al. (2017)" in their researches suggesting that the winning players are those who use a very quick defensive transition to protect their basket from a score (Gómez, Lorenzo, Sampaio, Ibáñez \& Ortega, 2008, p. 255; Gómez, Tsamourtzis, Lorenzo, 2017, p. 106).

One of the essentials of defense is that players must sprint from offense to defense (defensive transition) to protect the defensive basket from getting ease score (Krause, D. Meyer \& Meyer, 2008, p. 157).

Jon Oliver (2004) indicates that the very quick transition defense is important in the game of basketball because it helps players arrive at the defensive zone and protect the basket before the offensive team arrives (Oliver, 2004, p. 76).

The researcher proved that the very quick transition from offense to defense and vice versa was so important on the result in basketball matches, for as the very quick transition offense helps players scoring quick and easy baskets; very quick transition defense helps players protecting the basket from points, which is consistent with the objective of basketball game.

Alexander Franks et al. (2015) clarifies that "the two main objectives in the game of basketball are to score points on offense and to prevent points on defense" (Franks, Miller, Bornn \& Goldsberry, 2015, p. 1).

Jerry V. Krause et al. (2008) says that "offensive players attempt to take the ball toward the basket by passing or dribbling. Defenders must prevent this penetration whenever possible" (Krause, D. Meyer \& Meyer, 2008, p. 158). 
Thus, the hypotheses (1), (2) and (3) were achieved, but the hypothesis (4) was achieved partially, referring to "there are statistically significant differences between transitions in the results of the three teams coming at the three first places: (Al- Ahly club, Recreativo do Libolo club and AS Sale club) in favor of very quick transition offense and defense for Al- Ahly club". This difference came in favor of normal transition on offense for Recreativo do Libolo club because the mean of four to five seconds transition offense is greater than the mean of five to eight seconds transition, and also in favor of quick transition on defense for Al- Ahly club because the mean of one to three seconds transition defense is greater than the mean of no transition.

The researcher proved that the very quick transition offense and defense was so important on the result of basketball matches, but also other transitions on offense and defense were important on the result by different rates, especially normal transition on offense (four to five seconds) and quick transition on defense (one to three seconds).

These findings are consistent with "Miguel Ángel Gómez et al. (2008)" in their research which indicates that "the common aspect of the successful teams in basketball matches is their cooperation on both defense and offense" (Gómez et al., 2008).

The researcher proved using FIBA official website teams' statistics, that Al- Ahly club got first place in blocks and second place in rebounds, and showed also from her analysis using the Utilius ${ }^{\circledR}$ vs advanced version (4.5.8) that Al- Ahly club got first place topping the first three winning places on quick transition defense (one to three second), which means when Al-Ahly transition quickly from offense to defense (defensive transition) it helps the team arrive quickly to defense zone, facilitating taking their defense position to make easy blocks and rebounds to preventing their opponent from scoring points. This explains why Al-Ahly club got first place at FIBA Africa Champions Cup for men (2016) and won all the matches the team played without any loss, however, the teams coming at the second and third places lost two of their matches.

Morgan Wootten and Joe Wootten (2013) indicate that "the most successful basketball clubs and coaches are the ones who are best at preparing their team for each game by training players to make quick 
transitions, especially from offense to a defense" (M. Wootten \& Wootten, 2013, p. 235).

Players and coaches should be aware of these results "the importance of all types of transitions from offense to defense and vice versa on the results of basketball matches, especially (one to three seconds) and (four to five seconds) on transition offense, (zero second) and (one to three seconds) on transition defense " in order to have a better control on the training and the game played depending on its development.

\section{Conclusion:}

The very quick transition offense "one to three seconds" and normal transition offense "four to five seconds" had positive effect on the result in basketball matches, helping players score points easily; very quick transition defense "Zero second" and quick transition defense "one to three seconds" had positive effect on the result in basketball matches, helping players prevent their opponents from scoring points, as well as make easy blocks and rebounds. Players and coaches should take in account the importance of transitions, both offense and defense.

\section{Reference}

Cárdenas, D., Ortega, E., Llorca, J., Courel, J., Delgado, G. S., \& Piñar, M. I. (2015). Motor Characteristics of Fast Break in High Level Basketball. Kinesiology. 47(2), 208-214

Chen, W., Lao, T., Xia, J., Huang,X., Zhu, B., Hu,W. \& Guan, H. (2016). GameFlow: Narrative Visualization of NBA Basketball Games. JOURNAL OF LATEX CLASS FILES. 14(8), AUGUST.

FIBA - International Basketball Federation. (2016a, Dec 17). History made as El Ahly win FIBA Africa Champions Cup 2016. Retrieved from http://www.fiba.com/africa/championscup/2016/news/history-made-as-el-ahlywin-fiba-africa-champions-cup-2016-arnold-scoops-mvp-award

FIBA-International Basketball Federation. (2016b, Dec 28), TEAMS STATISTICS FIBA Africa champions cup 2016 for men. Retrieved from http://www.fiba.com/africa/championscup/2016/teamstats\#tab=team_stat

FIBA - International Basketball Federation. (2002) FIBA Africa Champions Cup. Retrieved From http://www.fiba.basketball/africa-champions-cup. 
Franks, A., Miller, A., Bornn, L. \& Goldsberry, K. (2015). Counterpoints: Advanced

Defensive Metrics for NBA Basketball. 9th annual MIT SLOAN, sport analysis conference. Boston: Boston convention and exhibition center.

Gómez, M. A., Lorenzo, A., Sampaio, J., Ibáñez, S. J. \& Ortega, E. (2008). Game-Related Statistics that Discriminated Winning and Losing Teams from the Spanish Men's Professional Basketball Teams. Coll. Antropol. 32 (2), 451456.

Gómez, M. A., Tsamourtzis, E. \& Lorenzo, A. (2017). Defensive systems in basketball ball possessions. International Journal of Performance Analysis in Sport. 6(1), 98-107.

Haefner, J. (2010, Apr 12). An Easy Way Improve Transition Offense [Online Article].

Retrieved from https://www.usab.com/youth/news/2010/04/an-easy-wayimprove-transition-offense.aspx

Hassan, O. (2000). Fast break and it's Relation to Matches Results in the African Champion of cup's Hero Clubs for Handball Female (Unpublished doctoral dissertation). Helwan University, Egypt.

Hosny, A. (2008). Analytical study of the effectiveness of fast break types and its relationship to match results in basketball (Unpublished master's thesis). Alex University, Egypt.

Krause, J. (1994). Coaching Basketball. 2nd ed. United States of America: NTC/Contemporary.

Krause, J. V., Meyer, D., Meyer, J. (2008). Basketball skills \& drills. 3rd ed. united states of

America: Human Kinetics.

Krause, J. V., Meyer, D. \& Meyer, J. (1999). Basketball skills and Drills. 2nd ed. United States of America: human kinetics.

Krause, J. V. \& Pim, R. (2002). Coaching Basketball: Revised and Updated. United States of America: contemporary Books.

Lenox, D. \& Murphy, R. (2010, Dec 13). Basketball coaching guide - Planning a Basketball Training \& Competition Season [Online Book]. Retrieved from https://issuu.com/rinoco/docs/basketball_coaching_guide

Mohammed, A. R. (2013). Analysis of the performance ratios and systematic attack the hijacker teams emerging Iraq handball. Journal of Physical Education Sciences. 6(4), 388- 423

Monier, T. (2008). The relationship of the fast break with the results of the basketball matches (Unpublished master's thesis). Banha University, Egypt.

Oliver, J. (2004). Basketball fundamentals. United States of America: Human kinetics.

Peterman, C. (2014, Dec 13). Travis Ford: Transition Defense \& Defending the Ball Screen [Online Book]. Retrieved from https://www.mensbasketballhoopscoop.com/travis-ford-transition-defensedefending-ball-screen/ 
Swope, B. (2012). Teach'n Beginning Defensive Basketball Drills, Plays, and Games Free Flow Handbook [Online Book]. Retrieved from https://books.google.com.eg/books?id=HI5OrU6zwNQC\&pg=PA1\&lpg=PA1 $\& \mathrm{dq}=$ Bob+swope+(2012):\%22+teaching+Beginning+offensive+Basketball-

Wootten, M. \& Wootten J. (2013). Coaching Basketball Successfully. 3rd ed., United States of America: Human Kinetics. 